\title{
Imagens precárias: inscrições tênues de violência ditatorial no Brasil
}

\author{
Márcio Seligmann-Silva ${ }^{1}$
}

\begin{abstract}
A artista brasileira Rosângela Rennó, na série Vaidade e violência (20002003) apresenta textos emoldurados escritos em preto sobre um fundo preto. Esse procedimento não deixa de lembrar as obras de Ad Reinhardt, o pintor expressionista abstrato, criador de obras black on black, que na sua série Abstract painting, dos anos 1960, traça linhas em preto sobre um fundo preto. O título da série de Rennó é uma irônica (auto) referência à relação entre imagem, escrita, arte e violência. Nessa série o texto que faz as vezes de foto refere-se a fotografias. No primeiro quadro lemos:

A imagem que ela diz guardar de seu algoz é a de um homem que confundia seus interlocutores quando assumia o comportamento frio, decidido e muito objetivo nos interrogatórios. Vinte anos depois, E.M., 41 anos, ex-militante do MR-8, ficou trêmula ao ver a fotografia recente do delegado D.P. e não teve dúvida em afirmar: "É ele mesmo! Essa fisionomia ficou muito forte para mim."
\end{abstract}

A cena retratada por Rennó é a cena de um reconhecimento ao mesmo tempo trágico e jurídico. Nessa cena, a imagem mental encontra uma imagem fotográfica e provoca uma reação parecida com a que temos diante de pessoas. Trata-se aqui de uma imagem-pessoa ou imagemcorpo, de um torturador, que estava inscrita na memória da enunciadora e foi reconhecida na imagem fotográfica. Mas, na obra de Rennó, a única imagem que vemos é a de palavras em preto em uma moldura e fundos pretos, que para serem lidas exigem o constante deslocamento do leitor para conseguir extrair o texto da página negra que brilha.

Rennó fornece apenas as iniciais da torturada (E.M.: ex-militante?) e do algoz (D.P.: delegado de polícia?), transformando esse reencontro em uma espécie de evento coletivo, que marcou um país, o Brasil, já que o MR-8 é explicitamente mencionado. Essa obra é um dispositivo que permite pensar as imagens fotográficas como inscrições que devem ser lidas, ao mesmo tempo que aponta para o ser imagem da escrita. Toda imagem tem algo verbal, simbólico, que pode ser interpretado e traduzido - de " $\mathrm{n}$ " maneiras

\footnotetext{
${ }^{1}$ Doutor em teoria literária, professor do Instituto de Estudos da Linguagem da Universidade Estadual de Campinas (Unicamp), Campinas, SP, Brasil. E-mail: m.seligmann@uol.com.br
} 
- pelo receptor, mas toda imagem tem também restos não verbalizáveis. As imagens são ao mesmo tempo verbais e mudas. Assim como existem ausências de palavras diante de certas imagens, existem também cenas que deixaram imagens - embaçadas, traumáticas - apenas na mente de certas pessoas. A ausência de imagens das torturas é parte do buraco negro da memória da violência da ditadura. A violência dos atos brutais do terrorismo de Estado acontecia ao mesmo tempo que a tentativa de se apagarem os seus rastros. Havia um tabu da imagem em torno das câmaras de tortura. Também a impossibilidade de testemunhar aquela cena que se passou na câmara obscura está indicada na impressionante obra de Rennó. $\mathrm{Na}$ imagem, o preto sobre preto mostra o colapso da representação, o sucumbir do preto e branco fotográfico - mas também a necessidade de inscrição, mesmo que apenas tentativa, do passado.

Pretendo apresentar aqui algumas considerações sobre essas tentativas de inscrição do passado, com ênfase no caso da última ditadura civilmilitar brasileira de 1964-1985. Para tanto farei algumas incursões nos debates e trabalhos sobre o tema da representação ditatorial em outros países da América Latina. Em uma era de globalização, também a cultura da memória e da recordação se tornou profundamente transnacional. Impossível tratar desse tema da memória pós-ditatorial no Brasil sem falar de seus vizinhos. Também operarei segundo uma abordagem transmidiática: partindo das obras de Rosângela Rennó - sem dúvida, um das artistas latino-americanas que mais longe foram nessa tentativa de desenvolver e refletir sobre uma arte a partir do trauma (que não é nem arte da memória nem do esquecimento) -, passo por alguns fotógrafos brasileiros e hispano-americanos para chegar a dois autores que procuraram inscrever a experiência da ditadura em dois romances de épocas bem distintas: Renato Tapajós, com seu Em câmara lenta, de 1977, e Urariano Mota, autor de Soledad no Recife, de 2009. Nesse percurso farei também algumas rápidas incursões no cinema brasileiro sobre a ditadura, a mídia que mais profundamente foi na tentativa de inscrição e elaboração daquele período da história do Brasil.

\section{Foto e trauma}

Ernst Simmel, autor de Kriegsneurosen und psychisches Trauma ("Neuroses de guerra e trauma psíquico", 1918), descreveu o trauma de guerra com uma fórmula que deixa clara a relação entre técnica, trauma, 
violência e o registro de imagens: "A luz do flash do terror cunha/estampa uma impressão fotograficamente exata" (Simmel apud Assmann, 1999, p. 157 e 247). A fotografia é um dos dispositivos mais potentes quando se trata de se visualizar a inscrição mnemônica e não por acaso Freud recorreu a ela para pensar nossa psique, marcada pelas inscrições traumáticas. A foto é um testemunho de um presente e, como todo testemunho, oscila entre a possibilidade de representar um evento (testemunho como testis) e o colapso dessa representação (testemunho como superstes, sobrevivente). A partir dessa duplicidade aporética e sem solução o testemunho se transforma em performance: em ato mimético cujo momento catártico está sempre a ponto de sucumbir. O testemunho é um umbral para a "libertação" do momento invisível que ele porta, mas essa passagem é enfeitiçada. Nada garante que a rememoração testemunhal nos liberte do trauma. Daí muitos dos autores de grandes testemunhos terem mesmo assim levantado a mão contra si mesmos, como Primo Levi, Jean Améry e Tadeusz Borowski, o mesmo tendo se passado com autores de testemunhos que morreram no anonimato, como Anja Spiegelman, mãe da Arte Spiegelman. O testemunho procura enquadrar o passado traumático, mas a "fotografia" às vezes permanece "cega".

Na série Parede cega (1998-2000), de Rosângela Rennó, vemos várias molduras, que lembram molduras fotográficas tradicionais, só que sem imagem alguma. O título Parede cega - uma parede sem abertura remete à ideia de que normalmente a fotografia emoldurada na parede pode ser percebida como uma janela aberta no espaço-tempo. Nessa obra de Rennó, as fotos emolduradas são apresentadas como que afundadas na parede, como se elas tivessem sido viradas de costas. $\mathrm{Na}$ verdade trata-se de fotografias doadas ou adquiridas em feiras de artigos de segunda mão (Rennó, 2003, p. 62), que foram pintadas e colocadas sobre painéis de espuma e lycra e fotografadas por Vicente de Mello. Podemos interpretar essas fotos pintadas de cinza como espelhinhos cegos - ou como fotos cegas. A cor da obra remete à cor de um negativo fotográfico ou ao sépia das fotos antigas. Tudo é cego nessa obra que revela o ponto cego da nossa visão fotográfica. Ao olharmos essa série vemos apenas a falta, a desaparição, sem seu avesso de presença, sem o enfático "isto foi - isto é" que toda fotografia parece dizer. Vemos apenas o "isto não é", ou - pensando em termos de uma economia sublime, de uma estética do silêncio e da falta para indicar o irrepresentável - assistimos nesta obra simplesmente ao "Isto é" ou o 
"How it is" becketiano. Vemos a imagem como pura performance, sem o lastro da referencialidade. Trata-se do dispositivo fotográfico de apresentação cegado e que remete a uma espécie de cegueira que também constitui a recepção da fotografia. Podemos pensar, assim, que a moldura da foto é essa própria cegueira, uma falta e um desejo que quer se saciar na inscrição de luz - que nesse caso não acontece na sua totalidade. Encontramos apenas molduras vazias. Suportes à espera de um olhar. Rennó com essa obra aponta para uma crise da representação no seu sentido documental. A fotografia-documento torna-se parede cega: local de projeção de fantasmas e desejos - local do desaparecimento, da ausência e não da presença, como costumamos ver as fotos. Estamos, talvez, diante do nascimento, de dentro da fotografia analógica, da pós-fotografia. Não por acaso Rennó só pode ser considerada fotografa em um sentido amplo do termo: ela mesma não faz o "clique", a captura das fotos, mas, antes, as "capta", se apropria delas em mercados de pulga e em arquivos. Ela é como que uma tradutora de fotos: ela transpõe imagens técnicas para novos contextos, como uma colecionadora, dando uma sobrevida às imagens ao mesmo tempo que reflete sobre o tempo e seu arruinamento. As imagens adquirem, assim, o caráter de resto e de ruína. Elas são partes de um processo, processamento e Durcharbeit (elaboração) de um passado que tem em seu centro a história de violências.

Em Imemorial, Rennó já fizera, em 1994, um impactante trabalho de memória e de tentativa de escovar a história a contrapelo. Nessa obra ela reuniu 50 fotografias a partir de um enorme arquivo abandonado que ela encontrou no Arquivo Público do Distrito Federal referente à construção de Brasília. Sabe-se que inúmeros trabalhadores, os chamados "candangos", morreram de modo trágico durante a construção de Brasília, que pontuou o governo do presidente Juscelino Kubitschek: uma cidade construída em menos de quatro anos, com exploração abusiva dos trabalhadores (com jornadas de 14 a 18 horas) e repressão à bala das suas tentativas de organização e revolta. A apresentação do trabalho de Rennó é uma homenagem aos mortos, sendo que as fotos, ampliações de fotos deterioradas $3 \times 4$ encontradas no arquivo abandonado e esquecido, apresentam uma forte ambiguidade, oscilando entre as imagens de cerimônias oficiais de recordação e o esquecimento das vítimas anônimas do "progresso" e da "civilização". O título "Imemorial" faz lembrar o conceito de counter monument, que passou a 
ser empregado nessa mesma época por teóricos da memória da Shoah como James Young. Essas expressões remetem à aporia contida em todo ato de recordação de eventos traumáticos, que é agravada conforme a dimensão e intensidade da catástrofe que originou o trauma. No caso de Imemorial trata-se de iluminar o outro lado da ideologia desenvolvimentista, do culto cego ao progresso, de mostrar a falsidade da utopia-Brasília, que significou a morte de candangos, bem como a expulsão dos pobres para as cidades-satélite. Rennó nos faz ver o lado distópico daquela capital, ironizando, ao mesmo tempo, de modo crítico, os rituais e memoriais oficiais. Como nos trabalhos de artistas vinculados ao antimonumento, como Jochen Gerz e Horst Hoheisel, Rennó, por meio de inversões, nos faz ver o esquecido, o socialmente recalcado: no caso, os trabalhadores mortos que ficaram enterrados nos alicerces da capital, macabras pedras fundamentais sem nome, em cujas carteiras de trabalho consta apenas a frase cínica: "dispensado por motivo de morte". Como em outros trabalhos, também aqui Rennó nos faz ver os desaparecidos.

A Série vermelha (militares), de 1996-2000, também é uma interessante mostra do trabalho de Rennó como uma artista que se apropria de fotografias para, em seu gesto de recolecioná-las, ressignificá-las e dar nova vida a elas. No caso, são fotos de homens com uniforme cuja preparação artística como que revela o "teor vermelho" das imagens. O presente, o líquido revelador no qual a colecionadora banha suas imagens, destaca do material fotográfico passado aquilo que, quando ocorreu a captura da imagem, não necessariamente estava visível. Dando seguimento a uma leitura feminista e antifalocêntrica da cultura, Rennó faz aqui outro tipo de antimonumento, que também faz uma espécie de reversão, mas, dessa feita, ao invés de elevar e expor os esquecidos, ela como que reverte "para baixo" aqueles símbolos do poder e da opressão. O elemento representacionista, a clareza da foto, é substituído por uma opacidade conquistada com o recurso do avermelhamento da imagem. Vemos mais ao vermos menos. O ser precário daquilo que parece ser a principal função da fotografia de retrato é um ganho, dentro da perspectiva artística aberta por Rennó.

A série Corpos da alma II (1990-2003), um conjunto de fotografias de jornal editadas digitalmente, trabalha com fotografias dentro de fotografias. Pessoas carregam fotos em passeatas ou em ambientes familiares. Essas pessoas que se transformam em porta-retratos são apresentadas em 
imagens ampliadas de tal modo que explicitam seu caráter de fotos de jornal, com seus pontos fotográficos superdimensionados. Aqui é a fotopresença, a foto-corpo, que está em jogo. A fotografia é apresentada como um Ersatz das pessoas, sejam elas líderes políticos ou parentes desaparecidos. A fotografia se apresenta aqui também como testemunho: de uma fé política, testemunho jurídico, ou ainda, testemunho dos fatos, tal como costumamos ver (e crer) nas fotos dos jornais. As fotos de fotos servem para apresentar a fotografia como um dispositivo capaz de incorporar outras imagens. Trata-se de uma meta-imagem, imagem da imagem que aponta para as imagens como criação e construção do mundo, no mesmo gesto em que, paradoxalmente, apresentam as imagens como foto-corpo, imagens-pessoas: quase que de carne e osso.

Por último dentre os trabalhos de Rennó e no contexto dessa reflexão sobre a inscrição da violência, destaco uma obra da série Cicatriz (19962003). Nessa série vemos a cada página, alternadamente, fotos de fragmentos de corpos com suas tatuagens - extraídas de negativos fotográficos do Museu Penitenciário Paulista - e fotos de fragmentos de peles recobertas com inscrições, como se estas tivessem sido realizadas sobre a pele, queimando-a. Os textos, como na série Vaidade e violência, também dizem respeito a fotografias. No exemplo que destaco lemos na inscrição queimada sobre a pele:

Há cerca de quatro anos, um senhor de fisionomia triste procurou C., restaurador de fotografias, em seu estúdio. Queria que ele lhe restituísse à memória a imagem de sua mãe, morta anos atrás. Porém, só guardara uma foto dela, morta, dentro do caixão. "Aquele senhor queria uma foto em que sua mãe aparecesse cheia de vida. Seria impossível fazer isso apenas restaurando aquela foto. Pedi que me descrevesse como eram os cabelos, os lábios, os olhos dela. A partir da descrição, tirei-a do caixão, desenhei-lhe um vestido bonito, abri seus olhos. Quinze dias depois, o homem voltou e quando viu a foto, chorou", lembra o restaurador.

O texto inscrito sobre a pele-pergaminho é uma pequena e contundente narrativa. Nela a presença da fala em primeira pessoa, na voz do restaurador, torna tudo mais imagético e intenso. O texto é apresentado como um ato de memória, ele se fecha com a expressão "lembra o restaurador". Todo texto é registrado na pele, como uma cicatriz, metáfora potente da memória traumática. A narrativa da ressurreição da mãe via fotografia novamente remete à força vital da 
imagem fotográfica: se na série Parece cega vimos a desaparição da fotografia, na Corpos da alma II as fotos representavam pessoas desaparecidas que continuavam a viver apenas nas fotos. Já aqui em Cicatriz vemos mais do que a sobrevida, vemos o próprio renascer via restauração fotográfica. O fotógrafo proclama: "abri seus olhos". Essa imagem abala e "faz chorar", tanto quanto as imagens de desaparecidos que sabemos que não poderão mais ser renascidos. Essa mãe que ganha vida pela intervenção do fotógrafo-artista-demiurgo remete novamente a essa força presencial da imagem fotográfica: ela é tão forte e intensa quanto as imagens reais de pessoas. Daí desde o século XIX se falar na capacidade como que espectral da fotografia de captar fantasmas e pessoas ausentes. Nesse trabalho vemos várias metamorfoses: a mãe que morrera e fora transformada em imagem fotográfica que depois, a partir da descrição - ekphrástica - que o filho faz dela, volta a ter vida graças à intervenção do restaurador, esse artesão cujo trabalho é reverter (ou elaborar) o desgaste do tempo. Mais do que nunca, nessa imagem da mãe ressuscitada vemos uma indicação da força vital da imagem fotográfica, com sua capacidade de nos abrigar, como em um útero analógico (ou eletrônico).

A bidimensionalidade da imagem fotográfica não rouba dela essa sua fantástica força presencial. As fotos de forte teor indicial e icônico, com caráter de foto-presença, de certa forma revertem a função aurática benjaminiana, uma vez que Benjamin via na aura "uma teia singular, composta de elementos espaciais e temporais: a aparição única de uma coisa distante, por mais perto que ela esteja" (Benjamin 2012, p. 184). O próprio Benjamin viu que a fotografia - como arte pós-aurática - tinha justamente a capacidade de aproximar coisas do indivíduo, distantes no tempo e no espaço (Benjamin 2012, p. 108). Nela se unem transitoriedade e repetibilidade: como nas imagens do trauma a que me referi acima. Mas em Cicatriz, a foto-cicatriz, foto-traço, nasce em nossa fantasia a partir da leitura de uma inscrição. Novamente vemos a proximidade aporética que Rennó cria entre imagem e cegueira, ver e imaginar, iconofilia e iconoclastia. As imagens, como nas sombras e nos fantasmas nas tragédias de Shakespeare, estão banidas em um limbo e não podem ser representadas, mas apenas sugeridas via performance. Esse reino espectral põe em ação traumas históricos e sociais de uma artista que viveu toda sua formação sob uma ditadura civil-militar que atuava na desaparição de seus opositores. Atget fotografou as ruas de Paris "como quem 
fotografa o local de um crime. Também este local é deserto", comenta Benjamin. Ele "é fotografado por causa dos índices que ele contém. Com Atget, as fotos se transformam em autos no processo da história." O mesmo podemos pensar com relação a essas obras de Rennó. Essa artista do esquecimento e de sua elaboração crítica.

Durante a ditadura brasileira de 1964-1985 alguns fotógrafos jornalistas conseguiram a façanha de fazer essa crítica em meio a um clima de censura e repressão. Luis Humberto, que trabalhou no Jornal de Brasília entre 1973 e 1979 (Fernandes Junior, 2003, p. 156; Barbalho, 2006), fez uma fotografia autoral profundamente crítica dos donos do poder. Ele mostra as paisagens desoladoras de uma Brasília dominada por militares em seus rituais vazios e ilhados do resto do país. Também o na época jovem jornalista fotográfico Orlando Brito captou de modo irônico e sagaz instantâneos da ditadura que revelavam a relação violenta e autoritária dos militares e demais donos do poder com a população.

As fotos de identificação, criadas no final do século XIX para controlar as populações, foram transformadas na América Latina em poderosas fontes documentais para comprovar a existência dos desaparecidos. Foram essas fotos, ao lado das extraídas dos álbuns de família, que foram ampliadas e anexadas aos laudos apresentados ainda durante as ditaduras, exigindo do Estado a restituição dos corpos - o habeas corpus que havia sido suspendido no estado de exceção que imperou em muitos países da América Latina dos anos 1970 e 1980. Um caso paradigmático nesse contexto é o do fotógrafo chileno Luis Navarro. De Altofagasta e sendo perseguido após o golpe de 1973, ele acabou indo para Santiago no final de 1974. Lá começou a trabalhar na Vicaría de la Solidariedad. Nessa posição ele foi responsável pelas fotografias do importante caso Lonquén, o primeiro sítio clandestino descoberto com cadáveres de desaparecidos em 1979. Nas comemorações do Tedeum na Catedral de Santiago, feito para comemorar em 11 de março de 1981 a proclamação da nova constituição, Navarro foi preso e posteriormente torturado. Graças à intervenção do cardeal Raúl Silva Henríquez e de organizações internacionais, ele foi libertado. Essa prisão, como destaca o historiador da fotografia chileno Gonzalo Leiva Quijada (2004, 2008), serviu de impulso para a fundação da AFI: a Asociación de Fotógrafos Independientes. Essa organização teve um papel fundamental durante a ditadura chilena, apoiando o trabalho de importantes fotógrafos, dando credenciais a eles e os defendendo dos ataques das forças do governo. 
Além do próprio Navarro, participaram da AFI fotógrafos como Paz Errázuriz, José Moreno, Hellen Hugues, Rodrigo Casanova, Álvaro Hoppe, Cláudio Bertoni, Jorge Ianiszewski, Leonora Vicuña, Kena Lorenzini e Rodrigo Rojas (assassinado pelos membros da ditadura em 1986, quando tinha apenas 19 anos, de modo bárbaro, queimado vivo ao lado da jornalista Carmen Gloria Quintana).

Luis Navarro é um dos responsáveis pela introdução das fotos ampliadas de carteiras de identidade e de fotos de família: essas imagens não apenas serviram para dar início aos processos contra a ditadura mas também foram parte integrante das ações dos familiares e amigos dos desaparecidos. Gonzalo Leiva Quijada considera essas fotos o maior fato na história da fotografia no Chile desde seu início no país em 1840. Nas manifestações no final dos anos 1970 os familiares portavam essas ampliações de fotos. A demanda dos corpos se fazia com aquelas imagens-testemunho. Navarro também fotografou outras vítimas do governo autoritário, os marginalizados economicamente, assim como captou a vida cotidiana em fotos com forte marca autoral, como notou Leiva Quijada. Sua fotografia de seu pai, reagindo à narrativa de sua prisão, quando leva uma das mãos diante dos olhos, tem uma rara força narrativa. Suas fotografias da mise-en-scène do poder também são importantes e apontam para uma característica das fotografias sob ditaduras: o fotógrafo muitas vezes tenta capturar imagens da esfera do poder, que, na mesma medida em que documentam, permitem construir alegorias e narrativas críticas. Assim a foto de um Tedeum em 1980 capta com certa ironia a pompa e austeridade militar sendo como que desprezada por um pombo que caminha exatamente em meio a uma trilha que vai na direção oposta àquela para onde se voltam os militares. O tempo frutífero, típico das imagens sem movimento, assume no fotojornalismo um significado muito mais radical. Aqui o disparo do obturador pode significar também um tiro certeiro no poder.

Uma impressionante foto de Luis Weinstein, também ex-membro da AFI, mostra um rapaz fotografando, diante da La Moneda, uma foto desse prédio quando do ataque no golpe de 11 de setembro de 1973. Vemos aqui como a memória migra para a era digital, transformando o passado em fotografia de fotografia de fotografia. Weinstein se coloca como que por detrás de uma série em vertigem de imagens e reproduções, para mostrar o processo de telescopagem do tempo, de presentificação do passado que se torna imagem eletrônica. 
Já o catálogo Nexo, de 2001, do fotógrafo e artista argentino Marcelo Brodsky, contém vários projetos e é apresentado por uma figura-chave nos atuais discursos sobre a memória, Andreas Huyssen. As obras nesse catálogo são imagens-ação, gestos, construções imagéticas com força performática. A primeira imagem do livro - fora a da capa - é a de um "siluetazo" em Buenos Aires. Essa foto e o texto evocam a força dessa modalidade de protesto, usual na Argentina da época da ditadura, e que ainda hoje é utilizada. A silhueta é uma marca comum na zona onde ocorreu um assassinato, e marca o local de um corpo morto. Ao mesmo tempo é um contorno que marca também uma falta: uma alusão à própria origem da arte que, na lenda grega de Dibutade, teria sido inventada por essa mulher, que decidiu pintar a imagem do seu amado, antes que ele partisse para uma guerra, a partir de sua sombra projetada na parede. Por outro lado, esse mito grego apresenta a imagem como algo secundário, platonicamente derivado de uma luz que emanaria de fora da imagem. Já nessas imagens fotográficas que tratamos aqui a luz como que provém da própria imagem. Não somos mais platônicos. Sabemos que as sombras somos nós mesmos e nossa cultura de entulhos e abjeção. Plínio, o Velho, narra a anedota de Psamenites, apontando para essa ideia que afirma a arte como o local de elaboração de uma falta e de um desaparecimento: "A questão das origens da pintura é obscura [...]. Entre os gregos uns dizem que ela foi descoberta em Sicyone, outros, em Corinto, mas todos afirmam como se iniciou por riscar com um traço o contorno da sombra humana (omnes umbra hominis lineis circunducta)" (Pliny, 1999, XXXV, 15). O que se passa na modernidade e, sobretudo, no nosso contexto latino-americano é uma reatualização como que brutal desse dispositivo. Ele agora é incorporado às ações políticas que demandam justiça e verdade. Tornase parte de uma nova arte da memória que com seus "siluetazos" reivindica a verdade.

\section{"É muito tarde"}

Essa pintura de silhuetas ou skiagraphia (escrita de sombras) deu-se no Brasil já durante a ditadura. Uma obra emblemática desse período é o romance de Renato Tapajós Em câmara lenta. Esse cineasta, conhecido por seus documentários, como Linha de montagem, sobre as greves no ABC de 1979-1981, ficou preso de 1969 a 1974, devido a sua participação na 
organização Ala Vermelha, de guerrilha urbana. Seu livro foi em parte escrito ainda dentro da cadeia e, segundo relatos do autor, foi contrabandeado para fora da prisão por pessoas que o visitavam e transportavam os textos em pequenos rolos de papel escondidos na boca ou na roupa. Essa origem fragmentada do texto não deixa de se refletir na forma final do livro, publicado em 1977, como um mosaico de fragmentos. A cronologia não está totalmente ausente da ordem dos fragmentos, mas ela não é linear e lembra a montagem cinematográfica, com seu movimento de varrer os episódios com tomadas que vão e voltam na linha do tempo. O livro apresenta a história das organizações revolucionárias e de oposição ao governo ditatorial de 1964 a 1973, com ênfase no momento de maior repressão, quando a ditadura tentou dizimar toda e qualquer oposição. Trata-se de um romance que narra a situação de pessoas encurraladas, sem perspectiva de fazer triunfar sua luta revolucionária, vendo caírem um a um seus companheiros e a destruição das forças de oposição. Essa narrativa do encurralamento posteriormente foi explorada em vários filmes, como Nunca fomos tão felizes (1984), de Murilo Salles (baseado no conto Alguma coisa urgentemente, de João Gilberto Noll), Dois Córregos (1999), de Carlos Reichenbach, e Cabra cega (2005), de Toni Venturi.

$\mathrm{O}$ fato de o romance de Tapajós ter sido escrito em uma prisão transpira em cada frase do livro. A primeira delas abre a narrativa afirmando que "é muito tarde", e destaca desse modo o caráter de nachträglichkeit, de tentativa temporizada, après coup, atrasada, de reação ao trauma. A expressão "é muito tarde" é repetida ao longo de todo o livro. A clausura aparece em frases como esta: "Trancados nos aparelhos, saindo deles para fazer uma ação e voltar; sobreviver e gritar que ainda estamos vivos, até que eles nos localizem e nos matem. Fazer mais uma ação para poder esperar - vazia, carente de sentido, porque parte de um gesto já interrompido" (Tapajós, 1977, p. 50). A sintaxe aqui está fraturada. Tudo está interrompido aqui. O tempo do trauma é repetitivo e fragmentado. A memória dos fatos, mesmo que recentes, faz parte de um ruminar melancólico. O texto é descritivo, com poucas metáforas ou outras figuras de estilo. A fragmentação, diferentemente do que descreve Benjamin em relação ao Trauerspiel (o drama barroco alemão), não implica em alegoria, mas apenas no arruinamento da narrativa. "O tempo acabou", lemos ainda no primeiro fragmento: a narrativa rui, a linguagem se esgarça: "[A]s palavras não fazem mais sentido porque não nomeiam coisas" (p. 15). As frases muitas vezes ficam soltas, com a sintaxe cortada: 
"[E]u também morri lá, naquele dia, no momento quê" (p. 25). A quebra sintática ecoa as rupturas existenciais. Não existe tampouco uma voz narrativa clara: ela também se fragmenta em uma labiríntica trama de vozes. Se existe um predomínio da narrativa factográfica em terceira pessoa, às vezes em um mesmo fragmento o texto desliza dela para um "eu" com forte teor autobiográfico. Esse eu, contagiado pela figura autoral, tem recordações de Belém do Pará, terra de origem de Tapajós, e estudou em São Paulo, outra "coincidência" com a biografia do autor.

A sucessão de fragmentos é pontuada por uma narrativa-mestre, que é apresentada de modo repetitivo ao longo de todo a obra. Trata-se justamente do fragmento que dá nome ao livro e se abre com a frase "Em câmara lenta". Esse fragmento aparece pela primeira vez nas primeiras páginas (Tapajós, 1977, p. 16), com apenas 14 linhas, e vai se repetir mais quatro vezes (p. 25, 56, 87, 142) e, por fim, quase ao final do livro (p. 167-72), aparece já tomando 5 páginas. A cada aparição a descrição é acrescida de mais detalhes do fato traumático central na trama do livro. Trata-se de uma sequência na qual um grupo de guerrilheiros é parado em uma batida policial, a motorista reage matando um militar, para em seguida, após uma perseguição violenta, ser presa e barbaramente torturada até a morte. Toda a narrativa do livro deságua nessa narrativa da tortura, que acontece apenas na última e mais longa aparição desse fragmento. É como se o livro fosse uma tentativa de narrar o inenarrável, que surge aos pedaços, é apresentado aos solavancos. Ao fim, a narrativa da tortura é feita de modo detalhado, sem poupar o leitor, e desencadeia a cena final do romance: o eu narrador conta a sua própria morte enfrentando a polícia, tentando vingar a morte de sua ex-companheira, em uma ação assumidamente suicida. Essa repetição acompanhada de gradual detalhamento da cena, é típica da montagem cinematográfica e também do modo como, no cinema, se encenam os momentos mais trágicos, com seu involuntário flashback repetitivo, muitas vezes posto também em câmara lenta.

Essa fragmentação da memória do trauma normalmente leva, no cinema, como no famoso La jetée, de Chris Marker, ao abandono do movimento da câmara e ao puro encadeamento de imagens fotográficas estáticas. Em câmara lenta também tem essa tendência à foto. As narrativas são como flashes do passado. Em uma passagem lemos uma formulação que torna isso explícito. Na reclusão, uma voz pensa: "Ainda algum tempo para ficar em casa, olhando as sombras, os destroços, os fragmentos rasgados do passado. Os fragmentos rasgados 
do futuro" (Tapajós, 1977, p. 151). O narrador está à deriva em meio a essas imagens. A fotografia é justamente um fragmento de um aqui e agora. Os eus fragmentados da narrativa tentam construir com essas imagens espectrais um abrigo, precário, uma cápsula para se proteger de seu mal-estar, Unbehagen (desabrigo, desamparo ominoso), que parece não ter solução. Em um determinado momento, quando lemos sobre o enfrentamento ocorrido em outubro de 1968 entre os estudantes de direita do Mackenzie e os alunos da FFLCH-USP, na rua Maria Antônia, o estudante-narrador apresenta uma imagem quase fotográfica do momento em que José Dirceu, então presidente da União Estadual dos Estudantes, levantou a blusa ensanguentada do estudante secundarista José Carlos Guimarães, morto por uma bala. A narrativa com frases curtas e cortadas faz uma mise-en-scène da comoção:

Correu também para lá: Dirceu discursava em cima duma janela para a massa crescente. Falava do assassinato, propunha uma passeata até o centro. Os estudantes hesitavam. De repente, Dirceu levantou a camisa ensanguentada do menino morto e um urro surdo subiu da multidão. Um movimento, lento a princípio, e logo uma avalanche. Todos gritavam em cadência, o ódio explodia em cada voz [...] (Tapajós, 1977, p. 34-35).

No caso desse romance, o desfecho não deixa de apresentar também o entrelaçamento entre o luto da derrota política e o Trauerarbeit (trabalho de luto) da relação amorosa. A questão pública, que levou a um encurralamento, a um beco sem saída, como que empurra a narrativa para questões privadas, mesmo que essas sejam condenadas pelo decoro e código de honra dos envolvidos na guerrilha. O mosaico é composto por fragmentos de vidas recortadas pela força do Estado e que tentam se sustentar por relações que estabelecem em meio à luta, que são de ordem privada.

Não por acaso essa imagem da passeata com a blusa de José Carlos Guimarães em forma de bandeira nunca veio a se tornar parte da memória cultural no Brasil. Esse movimento em direção à privatização da dor já pode ser percebido no livro de Tapajós. Isso não apenas por conta do isolamento que ele descreve dos guerrilheiros e da falta de apoio à luta por parte da população, mas também por conta de uma percepção autocrítica do próprio movimento de guerrilha. Isso radicaliza a melancolia e a fragmentação da memória e do discurso. Eus rachados são apresentados como restos ejetados por uma máquina de terror: 
O que fizeram com ela? O tempo bate nos ouvidos, passa gota a gota, o mundo está arrebentado em milhares de pedaços, a casa vazia. [...] A vida rachou no meio. [...] Como um vaso que cai: estilhaçando em pedaços irregulares. [...] Estilhaços. Misturados no chão com uns restos de vida, um pedaço de rosto, uma frase, um livro rasgado. [...] é muito tarde. $\mathrm{O}$ que deixou de ser feito, nunca mais será feito (Tapajós, 1977, p. 38).

A destruição da luta revolucionária fez com que a lógica sacrificial nela implícita entrasse em crise. Nada mais justifica as mortes e os sofrimentos não há mais redenção: "Não admito e não permito que ninguém admita que todos os gestos foram sem sentido, que todas as mortes não serviram para nada, que a morte dela foi inútil. Eu sei que o gesto estilhaçou-se, não se completou, ficou no meio do caminho. Mas não pode ser [...] esquecido" (Tapajós, 1977, p. 48). Em outra passagem essa ideia é associada ao esmagamento de tempo e à obliteração do futuro e do sonho:

A vida é apenas, hoje, um adiamento da morte próxima, uma pausa entre quem sobrevive e aqueles que já morreram, porque eles levaram o que havia de futuro. [...] perdi a ponte que dá passagem ao futuro e estou acorrentado aos fantasmas. [...] $\mathrm{O}$ compromisso é com esses rostos que não existem mais [...]. Pertenço a eles porque eles morreram por uma coisa em que acreditavam e que eu não acredito mais (Tapajós, 1977, p. 83-84).

“[M]eu compromisso é com os mortos" (Tapajós, 1977, p. 160): com seus sonhos e com suas vidas sacrificadas. Essa consciência aguda da impotência e do fim da luta permite também um distanciamento irônico, trágico, da realidade da guerrilha. Ao lermos sobre "um tribunal revolucionário" que executou "o desertor devido ao perigo que ele traria a todo o plano" (p. 40), a descrição dos revolucionários guerrilheiros na Amazônia não é muito elogiosa: "Sonâmbulos de uma ideia grandiosa, meia dúzia de adolescentes exaustos, cambaleando para explodir um continente" (p. 40). Esses mesmos guerrilheiros tentam conquistar os caboclos para a sua causa, mas estes não entendem nada das ideias e propostas daqueles "adolescentes" (p. 41). Noutra passagem, a guerrilheira Marta afirma sobre seus colegas: "Vocês gostam mais das armas do que de gente." E dirigindo-se ao companheiro arremata: "Você não consegue sentir os outros" (p. 62). Esse isolamento emocional, assim como o político, levou a narrativa com seus vários eus fragmentados ao gesto da ação suicida final. A última frase do livro é 
inequívoca, sinal da única decisão possível: "A deserção definitiva tinha sido realizada" (p. 176).

Para terminar, gostaria de, mesmo que brevemente, apresentar outro romance sobre essa mesma violência ditatorial, mas escrito mais de três décadas após o livro de Tapajós. Trata-se de Soledad no Recife, do escritor pernambucano Urariano Mota. Esse livro descreve um caso que ficou relativamente conhecido no Brasil, ocorrido na capital pernambucana no início de 1973 e batizado com o nome de "massacre da chácara São Bento". Na verdade esse massacre não aconteceu nessa chácara, mas sim o delegado Fleury (que atuava no Departamento de Ordem Política e Social, o DOPS) e sua equipe haviam antes raptado e torturado até a morte seis membros da oposição à ditadura. Eles haviam sido denunciados pelo cabo Anselmo (apelido de José Anselmo dos Santos), um agente duplo que se infiltrara na oposição e foi responsável por mais de 200 mortes. Naquele dia 7 de janeiro de 1973, a equipe de Fleury montou uma farsa, colocando os seis cadáveres em uma casa da periferia de Recife e apresentando-os à imprensa como um grupo de guerrilheiros que havia sido assassinado após ter resistido à voz de prisão. No livro de Urariano Mota a personagem central, Soledad, é uma personagem histórica: uma das seis vítimas desse massacre. Soledad Barnett Viedma nasceu no Paraguai e, após exílio no Uruguai e em Cuba, encontrava-se em Recife nessa ocasião. Mota constrói um eu-narrador fictício, um poeta simpatizante da causa dos guerrilheiros, que se apaixona por Soledad e tem ódio de seu marido, Daniel - que na realidade é o próprio cabo Anselmo. Esse eu-narrador possui fortes semelhanças com o próprio autor, que em mais de uma ocasião declarou que de fato conhecia alguns dos membros desse grupo de jovens assassinados de modo bárbaro em 1973. Desde aquela ocasião ele guardou um vazio, uma sensação terrível de um crime monstruoso ocultado que precisava ser revelado e narrado.

O impressionante nessa obra é como ela se inicia de um modo claramente identificável como pertencente ao gênero romance histórico, mas aos poucos se esfacela e assume o caráter híbrido de ficção, reportagem e homenagem a Soledad. Citações de documentos oficiais, cópias de passagens de livros sobre a ditadura no Brasil, fotos de Soledad, imagens de jornais da época reproduzindo as mentiras oficiais sobre o massacre de São Bento dão um tom claramente testemunhal ao livro. A ficção sede à reportagem - ofício da profissão de Urariano Mota. O documento quer se sobrepor à ficcionalização como se esta fosse insuficiente para portar o 
testemunho dos fatos. Trata-se de um romance abortado, que abre mão dos códigos do gênero, sucumbindo sob o peso da história que narra e, sobretudo, do ódio e desejo de vingança contra Daniel - codinome de cabo Anselmo -, que não apenas se juntara à Soledad, mas veio a auxiliar no seu assassinato quando ela portava um filho deles no ventre. Essa violência e uma imagem que a representa tornam-se o umbigo e o ponto cego da narrativa. Essa "imagem crua" (Mota, 2009, p. 113), na expressão do próprio Mota, é apresentada no livro a partir de um testemunho da advogada Mércia Albuquerque, realizado em 1996, diante da Secretaria de Justiça de Pernambuco. Mércia vira os cadáveres do massacre 23 anos antes. $\mathrm{O}$ autor cita as comoventes palavras de Mércia:

Eu tomei conhecimento de que seis corpos estavam no necrotério [...] em um barril estava Soledad Barrett Viedma. Ela estava despida, tinha muito sangue nas coxas, nas pernas. No fundo do barril se encontrava também um feto. [...] Soledad estava com os olhos muito abertos, com uma expressão muito grande de terror. [...] Eu fiquei horrorizada. Como Soledad estava em pé, com os braços ao lado do corpo, eu tirei a minha anágua e coloquei no pescoço dela (Mota, 2009, p. 109-110).

O narrador comenta esse impressionante testemunho: "O seu relato é como um flagrante desmontável, da morte para a vida. É como o instante de um filme, a que pudéssemos retroceder imagem por imagem, e com o retorno de cadáveres a pessoas, retornássemos à câmara de sofrimento" (Mota, 2009, p. 110). Mota realiza em seu livro justamente esse movimento de passar o filme de trás pra frente, "imagem por imagem" - fotograma por fotograma, como em Tapajós - deixando Soledad viver ainda uma vez e seu narrador (o leitor) viver a paixão por ela. Seu trabalho de memória quer afirmar que aquele passado é e deve estar presente hoje: a ficção é essa mise en action do passado, é um despertar dos mortos e um clamor pela justiça. O narrador mesmo afirma que "a memória completa lacunas, ou melhor, recria a vida em lacunas, e, ao voltar, antecipa em 1972 o que sei 37 anos depois" (p. 56). Mota escreve a partir de uma falta no seu presente, a partir da perpetuação da injustiça, que o revolta, pois o cabo Anselmo ainda hoje anda livre e sem ter sofrido nenhuma penalidade pelas suas inúmeras barbáries cometidas. No Brasil a Lei da Anistia, de 1979, impede processos contra os torturadores. Por outro lado, já longe da melancolia derivada do fracasso político, Mota constrói um alter ego fictício como poeta apaixonado pela Tropicália, movimento que, como sabemos, desde o início teve sua 
reserva crítica com relação à luta armada. Desse modo o autor cria um observador de segunda ordem que pode descrever os fatos ocorridos em Recife no final de 1972.

Mota escreve já no e contra o espaço pós-histórico, como o surpreendemos na foto de Luis Weistein diante do Palacio de La Moneda. O passado é imagem, mas Mota o quer transformar em carne. Sua narrativa, que tenta fazer renascer Soledad dentro de um romance, acaba por desconstruir esse gênero, transbordando para um discurso testemunhal em primeira pessoa. Na era dos testemunhos, correlata à era das catástrofes, o romance, apesar de toda sua incrível plasticidade, é redimensionado pela necessidade de inscrição do trauma. Não por acaso o romance se abre com a afirmativa típica do testemunho jurídico: "Eu vi" (Mota, 2009, p. 19). Trata-se, no entanto, mais de um "eu vivi", ou seja, "eu sobrevivi àquela época dos anos de chumbo e quero atestar". A atestação da sobrevivência, ao lado da atestação factográfica, esgarça o gênero romance. O desvio pela ficção, que, como Levinas pensava, pode ser uma garantia de verdade e, portanto, não necessariamente avesso ao testemunho - como, entre outras, as obras de Jorge Semprun e Zwi Kolitz o comprovam -, parece não ser suficientemente sólido para a proposta de Mota. Ele dá um passo para fora e faz questão de usar seu indicador, o index, para deixar claro que devemos tratar a história de Soledad como história com " $\mathrm{h}$ " maiúsculo. Ele acumula provas: documentos e fotografias. Sua escrita da dor exige nomear os assassinos, dar as datas e locais, exigir justiça. O oitavo capítulo se abre com um subtítulo que rompe o fluxo da narrativa e faz sucumbir a ilusão até então construída: “Daniel, aliás, Jonas, aliás, Jônatas, aliás, Cabo Anselmo" (Mota, 2009, p. 63). Com essas palavras Mota põe um pé para fora do romance, ou ainda, seu romance se transforma em relato, récit. Nesse mesmo capítulo lemos uma interessante relação que é estabelecida entre a literatura e o papel de espião exercido pelo próprio vilão, o cabo Anselmo:

o espião - e a honestidade me obriga a dizer essa desagradável e dura frase - tem pontos em comum com o escritor. Porque a sua mentira se nutre da verdade. Digo melhor, corrijo, e me recupero do espinho: ele faz o caminho inverso do escritor, porque a sua é uma mentira que se nutre da verdade, enquanto o escritor serve à verdade, sempre, ainda que minta. A verossimilhança do espião é uma mentira sistemática que parte do real. A do escritor é verdade sistemática em forma de mentira, em forma de verdade, ou de reino híbrido (Mota, 2009, p. 66). 
Essa oscilação, ao determinar o que seria a verossimilhança do escritor - "em forma de mentira, em forma de verdade" - talvez esteja na base de uma opção, talvez não tão consciente, pelo quase abandono da "mentira" do escritor e pela passagem para os testemunhos, documentos, fotos e livros citados, como o caso do volume Direito à memória e à verdade, publicado pela Comissão Especial sobre Mortos e Desaparecidos Políticos da Secretaria Especial dos Direitos Humanos da Presidência da República, de onde Mota retira as biografias de Pauline Reichstul, Eudaldo Gomes da Silva, Evaldo Luiz Ferreira de Souza e José Manuel da Silva (Mota, 2009, p. 103-104), companheiros de luta de Soledad e igualmente assassinados naquela ocasião.

O último capítulo, o 13o, acaba por assumir a fusão completa, ou metamorfose, do narrador fictício em direção o narrador-autor do registro da egoescrita autotestemunhal. Mota lembra que, quando lançou seu primeiro romance, Os corações futuristas, também sobre o período da ditadura no Brasil de 1964-85, uma leitora profetizara que ele continuaria escrevendo sobre esse tema. Mota estava, como muitos de sua geração, condenado a repetir essa volta ao local do trauma. Essa paulatina passagem do eu ficccional para um eu-jornalista-escritorautor é uma resposta de Urariano à necessidade que sente de apresentar a verdade. O gesto "chega de brincadeira", quer lembrar que "a coisa é séria". Se a mimese artística é marcada pela ação recíproca entre a aparência e o jogo, Mota prefere galgar outro campo mais próximo a uma inscrição do real - por mais impossível que tal inscrição seja. Sua skiagrafia, seu contorno da silhueta de Soledad Barrett, forja sua forma de escritura sob o imperativo ético de atestar a verdade e servir à justiça em uma era liquida que faz a história virar jogo de aparência.

Poderíamos ainda nos perguntar o porquê dessa sua volta ao trauma, mas antes é importante lembrar que no Brasil esse tratamento do período da ditadura militar foi recalcado durante décadas. Com exceção dos últimos meses, marcados pela ação da Comissão de Verdade (instalada em maio de 2012 para tratar de crimes cometidos contra os direitos humanos de 1946 a 1988 no Brasil), até recentemente o tratamento desse tema era absolutamente recessivo na mídia, no Governo e no cotidiano brasileiro de um modo geral. No Brasil ocorreu uma privatização do trauma: apenas os familiares e pessoas próximas às vítimas, além dos próprios sobreviventes, se interessaram por esse tema e investiram na sua memória, na reconstrução da verdade e na busca da 
justiça. Daí o enorme papel de organizações como Tortura Nunca Mais e Comissão de Familiares de Mortos e Desaparecidos Políticos na tentativa de se buscar a verdade, a memória e a justiça. Não se desenvolveu no Brasil, e provavelmente não se desenvolverá, uma cultura da memória com relação àquela ditadura, assim como não se desenvolveu nesse país uma cultura da memória em relação ao genocídio indígena, ao de africanos e de afrodescendentes, à escravidão, à ditadura Vargas e à história das lutas no campo e nas cidades no Brasil. Com relação à ausência de memória pública quanto à ditadura de 64-85, podemos pensar na justificativa dada por um dos guerrilheiros do livro de Tapajós, que, destacando a diferença entre o Brasil e a Argentina, afirma: "[É] diferente na Argentina, lá o pessoal tem respaldo da massa" (Tapajós, 1977, p. 138). Ou então poderíamos pensar na acima referida autocrítica muito precoce entre os membros das organizações revolucionárias e de oposição no Brasil.

Também um recente livro sobre a ditadura, K., de Bernardo Kucinski, fecha-se destacando as execuções que eram feitas dentro das organizações revolucionárias, um dos temas mais polêmicos quando se trata de recordar a luta contra as ditaduras na América Latina, que, na Argentina, em 2004, desencadeou um interessantíssimo debate a partir de uma carta do filósofo Oscar del Barco, que defendia o mote "no matar" ("não matar") como base de qualquer ação ética-política. No livro de Kucinski, em uma correspondência acusatória contra um líder que está no exílio parisiense lemos as palavras: "Vocês condenaram sem prova, sem crime tipificado. Incorporaram o método da ditadura" (Kucinski, 2011, p. 174). Kucinski, como Mota, escreve com mais de três décadas de distância dos fatos. Também seu romance embaralha as cartas do testemunho e do romance, ainda que seu romance testemunhal seja mais amarrado e redondo que a obra esfacelada de Mota. Mas ambos fazem parte da construção a contrapelo no Brasil de uma cultura da memória e da verdade. Kucinski, que conta em seu romance a história de sua irmã Ana Rosa Kucinski, desaparecida na ditadura, e a saga de seu pai em busca da filha brutalmente assassinada, põe o dedo na ferida ao reclamar da falta de repercussão na esfera pública de um debate sobre a elaboração da violência da época da ditadura: "O 'totalitarismo institucional' exige que a culpa, alimentada pela dúvida e opacidade dos segredos, e reforçada pelo recebimento das indenizações, permaneça dentro de cada sobrevivente como drama 
pessoal e familiar, e não como a tragédia coletiva que foi e continua sendo, meio século depois" (Kucinski, 2011, p. 163).

Mas, para além dessa justa demanda de Kucinski, agora a política também deu uma virada subjetiva e passou a valorizar temas mais micropolíticos. Essa passagem da grande política para as ações de caráter mais individual e comunitário já havia sido retratada em um belo filme documentário de Lúcia Murat, Que bom te ver viva, no qual aparece Criméia Alice de Almeida Schmidt. Criméia é uma sobrevivente da guerrilha do Araguaia que lá perdeu seu companheiro e pai de seu filho. Falando de Criméia, a narradora do filme de Murat destaca a passagem da onipotência da guerrilha para as reuniões de mulheres onde se discute a política do dia a dia. "A dimensão trágica virou coisa do passado. E qualquer tentativa de ligação lembra um erro de roteiro" (QUE BOM, 1989). Isso já nos anos 1980. Mas é evidente que esse privilégio da micropolítica e descrédito com relação à grande política, aos grandes partidos e teorias abstratas que propunham a redenção na Terra não devem significar o abandono do reconhecimento público dos crimes cometidos durante a ditadura e seu esclarecimento. Enfim, essa autocrítica da esquerda, ao lado do pacto de silêncio e de esquecimento imposto pelas alas mais conservadoras da sociedade (no Governo e fora dele), garantiu que até hoje no Brasil, em contraste com a Argentina, Uruguai e Chile, a última ditadura ainda não tenha conquistado nem um lugar na memória coletiva nem um espaço no banco de réus. Talvez, e na verdade tenho certeza disso, uma coisa esteja intimamente ligada à outra. Por ora essa memória está restrita a essas e outras imagens precárias e tênues inscrições, como as que apresentei aqui. O elemento subjetivo predomina nessas inscrições, regado com fortes emoções em nó. No Brasil até o momento faltou-se ao encontro marcado com os mortos pela ditadura civil-militar e com seus sonhos.

\section{Referências}

ASSMANN, Aleida (1999). Erinnerungsräume: Formen und Wandlungen des kulturellen Gedächtnisses. München: C. H. Beck.

BARBALHO, Marcelo (2006). O fotojornalismo político no contexto da ditadura militar. In: ENCONTRO NACIONAL DE HISTÓRIA DA MÍDIA, 4., São Luís, 30 mai. a 2 jun. Disponível em: <http://goo.gl/2opkti>. Acesso em: 29 ago. 2008. 
BENJAMIN, Walter (2012). Magia e técnica, arte e política: ensaios sobre literatura e história da cultura. Tradução de Sérgio Paulo Rouanet, revisão técnica de Márcio Seligmann-Silva. 8. ed. rev. São Paulo: Brasiliense.

BRODSKY, Marcelo (2001). Nexo: Un ensayo fotográfico. Buenos Aires: La marca.

FERNANDES Junior, Rubens (2003). Labirinto e identidades: panorama da fotografia no Brasil (1946-98). São Paulo: Cosac Naify.

KUCINSKI, Bernardo (2011). K. São Paulo: Expressão Popular.

LEIVA QUIJADA, Gonzalo (2004). Luis Navarro: La Potencia de la Memoria. Santiago de Chile: Imprenta.

(2008). Multitudes en sombras, AFI. Santiago: Ocho Libros.

MOTA, Urariano (2009). Soledad no Recife. São Paulo: Boitempo.

PLINY (1999). Natural History. Books 33-35. Tradução de H. Rackham. Cambridge, London: Harvard University Press.

QUE BOM te ver viva (1989). Direção: Lúcia Murat. Produção: Kátia Cop e Maria Helena Nascimento. Distribuidora: Casablanca. DVD (98 min.).

RENNÓ, Rosângela (2003). Rosângela Rennó: o arquivo universal e outros arquivos. São Paulo: Cosac Naify.

TAPAJÓS, Renato (1977). Em câmara lenta. 2. ed. São Paulo: Alfa-Omega.

Recebido em dezembro de 2013.

Aprovado em janeiro de 2014.

resumolabstract

\section{Imagens precárias: inscrições tênues de violência ditatorial no Brasil}

Márcio Seligmann-Silva

Este texto apresenta uma reflexão sobre a difícil inscrição na memória cultural dos fatos violentos ocorridos na ditadura civil-militar no Brasil (1964-1985). Ele desenvolve uma análise da precariedade dessas inscrições, que têm que enfrentar a ausência de ressonância na esfera pública. A privatização do trabalho da memória bloqueia a elaboração lutuosa e jurídica dos fatos terríveis ocorridos naquele período. $\mathrm{O}$ autor procura mostrar as estratégias de apresentação desse passado e a sua difícil inscrição a partir dos trabalhos de artistas como Rosângela Rennó, de fotógrafos e de escritores, como Renato Tapajós e Urariano Mota. 
Palavras-chave: ditadura civil-militar brasileira, privatização da memória, arte da memória, skiagraphia.

\section{Poor images: faint markings of dictatorial violence in Brazil}

Márcio Seligmann-Silva

This text presents a reflexion on the difficulties of the inscription of the Brazilian civil-military dictatorship (1964-1985) and its violent stories. It develops an analysis of the precarious character of those inscriptions, which have to deal with an absence of eco in the public sphere. A privatization of the memory work blocs the mourning and the juridical elaboration of the terrible facts of that period. The author tries to show the strategies of presentation of this past and its tough inscription departing from the works of artists (as Rosângela Rennó), photographers and novelists (as Renato Tapajós and Urariano Mota).

Keywords: civil-military Brazilian dictatorship, memory privatization, art of memory, skiagraphia. 